Journal of K6, Education, and Management (J-K6EM)

Vol. 2, No. 2, 20I9, pp. I07-I I I. ISSN 2580-2I35

\title{
Education Management In Graduate Orientation
}

\author{
Rahmat Wirayudha ", Wahyu, Rustam Effendi \\ Graduate of Educational Management, Lambung Mangkurat University, Banjarmasin,70123, Indonesia
}

\begin{tabular}{|c|c|}
\hline ARTICLE INFO & A B S TRACT \\
\hline \multirow[t]{2}{*}{$\begin{array}{l}\text { Article history } \\
\text { Received: June } \\
\text { Revised: August } \\
\text { Accepted: September } \\
\text { Keywords: Education, Vo- } \\
\text { cational school, graduates, } \\
\text { Management }\end{array}$} & $\begin{array}{l}\text { Education graduates are more unemployed than those who work or are not in ac- } \\
\text { cordance with what the world wants. This doesn't only occur to bachelor, but also } \\
\text { to senior high school graduates, so the government responds to this by prioritizing } \\
\text { an education system whose link-and-match outcome as workers. Bridging this, } \\
\text { vocational school is one solution. Vocational High School (SMK) is an embodi- } \\
\text { ment of the school system with a vocational form, with various departments that } \\
\text { certainly respond to the diversity of the world of work available. Types of Voca- } \\
\text { tional Schools in Indonesia are attached in Appendix I. In this study, researchers } \\
\text { only focusing on Vocational School majoring in Pharmacy. As a vocational school, } \\
\text { The Pharmacy Department required to produce eligible graduates according to the } \\
\text { work field and industry standard. The standard should be applied to qualified of } \\
\text { work field and industry demands, Education Management is needed, which in- } \\
\text { cludes Planning, Implementation, Evaluation, and Supervision in the education } \\
\text { process in schools in such a way that the competencies, expertise, and skills of } \\
\text { graduates are in accordance with the demands of the world of work and industry, } \\
\text { schools rely on the rules of School-Based Management (SBM). As time goes by, As } \\
\text { time goes by, parents of vocational students want their children's ability to continue } \\
\text { into the next levels with good character, religious, and academics. The various de- } \\
\text { mands try to be fulfilled by schools by implementing various activities using } 8 \text { na- } \\
\text { tional education standards as a reference, which are applied through the school- } \\
\text { based education management concept. This study focuses on how each Planning, } \\
\text { Implementation, Evaluation, and Supervision of Education Management at ISFI } \\
\text { Pharmacy Vocational School and Husada Vocational High School Pharmacy } \\
\text { Study Program, which processes through the application of } 8 \text { National Standards } \\
\text { of Education in influencing graduate orientation. }\end{array}$ \\
\hline & $\begin{array}{l}\text { (C) (C) () } 2019 \text { The Authors. Journal of K6, Education, and Management (j-K6EM). } \\
\text { ISSN: 2580-2I35. Published by Graduated Program of Educational Manage- } \\
\text { ment, Universitas Lambung Mangkurat, Banjarmasin 70123, Indonesia. This } \\
\text { is an open-access article under the CC-BY-SA license. }\end{array}$ \\
\hline
\end{tabular}

*Correspondence: Rahmat Wirayudha; E-mail: rahmatwirayudha@gmaill.com 


\section{Introduction}

Educated unemployment is a problem for the nation. A large number of unemployed amid the increasing number of employment shows that there is a synchronization between the expertise needed by work field and the expertise possessed by prospective workers directly because they have expertise tailored to the needs of the work field. The Vocational school is an integral part of the National Education System which contributes to the growth of the national industry and economy, remain to be developed both in terms of quality and quantity. The focus of vocational education equips students with skills, mastery of knowledge, attitudes and professionalism and competencies needed in the world of work and industry, and also emphasizes learning by doing and hand on experience methods.

Based on Andriyani (2018), almost all people are subject to education. Education must be interpreted as an endeavor to assist humans to achieve their own reality by optimizing all of their potentials. All processes leading to the realization of optimizing human potential, regardless of place and time, are categorized as educational activities. (Moh.Shofian, 2004).

This makes parents of vocational students not only willing to wish for their children to be able to work in the work field and industry, but also demand that their children also have good character, religious and academic expertise to advance their education to a higher level.

To achieve this, the School must implement good Education Management. Arikunto and Yuliana define Education Management as an activity or series of activities in the form of a business management process in collaboration with a group of people who are parts of an educational organization to achieve predetermined educational goals to be effective and efficient. ISFI Pharmacy Vocational School and Pharmacy Study Program of Unggulan Husada Vocational high school.

This study focuses on how each of the Planning, Implementation, Evaluation, and Management of Education in ISFI Pharmacy Vocational School and Husada Vocational High School Pharmacy Study Program, which processes through the application of 8 National Standards of Education in influencing the graduate orientation

\section{Methodology}

This type of research is include a variety of qualitative information with detailed and comprehensive descriptions. This method is seen as relevant to the formulation of the problem that requires the writer to conduct a critical study in order to explain and understand intensive relations between data and data sources.

The case study in this research are Planning, Implementation, Evaluation and Supervision of Management of Education in ISFI Pharmacy Vocational Schools and Pharmacy Study Programs at Superior Husada Vocational School Banjarmasin, as well as the interaction of the four components of management in influencing graduate orientation. Sources of data taken in the following research came from Principals, Deputy Principals, Teachers, and also educational staff, as well as various documents relating to this research. Data collection techniques were interview, documentation, and observation. The data analysis technique is the analysis of cross-site data. Analysis of cross-site data has the purpose of comparing data and also integrating findings obtained from each site that has been studied.

\section{Findings and Discussion}

This study examines the Planning, Implementation, and Evaluation, and also Supervision of Education Management in schools that rely on School-Based Management where the Principal role as a chief Manager which considerably determines the success of the school.

Leadership and role models from the Principal as Managers in Education Management in schools will give impact on the Teacher, an as good influence on the teachers will enhance the performance of teaching and learning process. This is in line with the findings of Suhaimi \& Efendi which states that the importance of the Principal's role in relation to teacher performance in schools.

Schools are given full authority in the context of MBS. ISFI Pharmacy Schools and Pharmacy Study Programs of Unggulan Husada Vocational High School carry out learning planning through school year meetings involving all components of the Educator and education staff, then the Principal and Deputy Principals of the Curriculum section together with the teachers and the education office and representatives of the community through the school committee agreed on what curriculum will be used for learning in that year. The book Educational Planning (2014) says that good planning is the most likely plan to be implemented.

To carry out this learning certainly needed supporting facilities and infrastructure for learning 
theory and learning practice in a Pharmacy laboratory. All of this element planned thoroughly along with the making of School Work Plans and Budgets (RKAS) or School Expenditure Budget Plans (RABS) which are usually compiled at the initial meeting of the school year and the proposals are usually submitted by the Deputy Principal of the Facilities and Infrastructure section. This is a school authority in implementing Education Management, and consistent with the statement of Suhaimi \& Rinawati in a paper stating that schools have great authority in developing schools.

In Education Management in schools, the Principal together with the Deputy Principals, and Teachers and all academic community work together. they established the Vision, Mission, and School Objectives. Synergy between the Principal and the Deputy Principals and the entire academic society that occurs in Pharmacy Vocational Schools ISFI and Pharmacy study program of Unggulan Husada Vocational School by planning school activities in the beginning of the school year meeting in order making RKAS / RABS, then describing the implementation of all activities based on their respective parts, making all elements of school resources optimally utilized. The accordance of Alamsyah (Alamsyah, 2019) that School-Based Management can develop school progress in a better direction.

The development of science and technology, especially information technology and computer science requires to make adjustments and developments in the management of education, learning, and management of schools as a whole. The existence of ICT facilities for learning in addition to providing other nuances in learning for students also spurs teacher enthusiasm in teaching. This is steady with the findings of Permadi (Permadi, 2019) that the use of ICT media can spur teachers' enthusiasm in learningSFI Pharmacy School and Pharmacy Study Program of unggulan Husada Vocational School have furnished themselves with teaching devices based on Information and Computer Technology (ICT ) material such as Laptop and Projector in the classroom, also has a Language Laboratory and Computer Laboratory and has held a Computer-Based National Examination (UNBK) independently.

Another aspect of Education Management after Planning and Implementation is Evaluation. In learning, Evaluation is carried out both for students and for teachers. In the initial meeting of the school year, after the curriculum is agreed to be used, the teachers will develop a Learning Implementation Plan
(RPP). making lesson plans and supporting devices such as props and simulations is part of the Principal's Evaluation through the Deputy Principal of the Curriculum Section. Evaluations on Students are carried out by the Teacher with various instruments such as pre-test and post-test, and also mid-test and end of the semester. This is in line with Suhaimi \& Khalik's findings that the breakthroughs made by the Principal really determine the progress of the school The evaluation refers to the application of 8 National Standards of Education, for example for assessments referring to the Standard of Assessment and also the Competency Standards of Graduates. To obtain a qualified evaluation result, the Principal must be creative and make many breakthroughs. The teachers and students are enthusiastic in covering the evaluation.. To get quality evaluation results, the Principal must be creative and make many breakthroughs. The principal is the key to the success of the school. creativity and innovation are needed to make quality schools

As a vocational school, ISFI Pharmacy Vocational School and Pharmacy Study Program of Husada Vocational High School have a great responsibility to produce eligible graduates and good academic to continue their education. To get a qualified graduate, the school Planning, Implementation, and Educational Management Evaluation must obtain optimally. Supervision at ISFI Pharmacy Vocational School and Pharmacy Study Program at Unggulan Husada Vocational School are conducted in stages. Students are cared for and supervised by teachers in the classroom, teachers are supervised and nurtured by the Head of Study Program, teachers and study programs supervised and guided by Waka Curriculum, for the three of them are supervised and fostered by the Principal. The Principal will receive supervision and guidance from the supervisor of the local education office. Shools as a place to interact with the four components of Education Management require a good cultural condition to support the success of the educational process. School leaders with the academic community and the surrounding community must work together to build a culture of learning, hard work, smart work, honesty, tolerance, democracy and so on. A good school culture will affect the character of the graduates of the school to be good and will eventually be favored by the workforce users in the workforce who will later enter them. This is in accordance with Suriansyah's findings that schools 
must advance school culture to get good performance from school residents.

Schools also need a conducive environment for the educational process to take place. Environmental conduciveness consists of material The habit of prayer in congregation in the school mosque, recitation, and spiritual formation plays an important role in shaping the character and habits of students who are good and qualified religiously and scientifically. The habit of prayer in congregation in the school mosque, recitation, and spiritual formation plays an important role in shaping the character and habits of students who are good and qualified religiously and scientifically. This in accordance with the findings of Salasiah. The quality of a school is reflected by accreditation level that school has achieved. Behind the excellence of accreditation in a school, there is a great effort from the entire academic society, especially Principals as Chief Managers achieved accreditation B. The success of the two SMKs in achieving accreditation A and B, certainly unseparated from their respective Principals roles. This is in accordance with the study of Rachmadinoor (Rachmadinoor, 2018), who found that principals as managers, educators, and motivators greatly influence the quality of educational institutions.

Djohar (Djohar, 2007) recommends that vocational school as an educational program that prepares individual students to become professional workers and is ready to continue their education to a higher level. Based on the above opinion, that vocational school is more leading graduates to work readiness, but open the possibility to continue to a higher level (colleges, professions, etc.). The two schools have implemented the eight National Education Standards in the Education Management corridor with a slightly different level. These two Pharmacy Vocational Schools have become interest-attracting Magnets of students who want to pursue vocational pharmacy on the island of Kalimantan, especially South Kalimantan. This condition affects the orientation of Husada Vocational High School Pharmacy graduates. Many chose to pursue a career first in a new job and then went on to study. From tracer search studies, it was found that the majority of families of Husada Featured Vocational families came from the lower middle class.

\section{Conclusion and Recommendation}

1. Educational's Management Planning toward ISFI Pharmacy vocational school and Pharmacy Study Program of Unggulan Husada Vocational High
School were managed through the primary school year by a rally chaired by the Principal as the chief Manager, accompanied by Deputy Principals and the entire academic society. each Deputy Principal along with the Head of School Administration have submitted a proposal for the Work Program and Draft of their respective budget, then combined into the School Budget Plan.

2. In the Implementation of Education Management at ISFI Pharmacy Vocational School and Pharmacy study program of Husada Vocational High School, the references used are 8 National Standards of Education. All academic communities at ISFI Pharmacy Vocational School and Husada Vocational High School Pharmacy Study Program, work together to implement all existing plans to get the best results.

3. Planning and Implementation of education's Management at ISFI Pharmacy Vocational School and Pharmacy Study Program of Husada Vocational High School, has evaluated by the Principal in a tiered and constant demeanor. In terms of learning, students assessed by teachers, then the teachers are assessed by the Heads of Study Programs, the Head of Study Programs is assessed by the Curriculum Head, then the Curriculum Evaluation evaluated by the Principal.

4. The Plan and Implementation and Management Evaluation of Education in ISFI Pharmacy Vocational Schools and Husada Vocational High School Pharmacy Study Programs followed up with continuous and tiered Supervision. In terms of learning, students are supervised and nurtured by the teachers. After that, the teachers were supervised and nurtured by the Heads of Study Programs. Supervised and fostered by the Education Foundation and Office.

5. The four elements of Education Management interact together in addition to producing quality graduates who also influence the orientation of graduates of ISFI Pharmacy Vocational School and Husada Vocational High School Pharmacy Study Program. This condition affects the orientation of Husada Vocational High School Pharmacy graduates. Many chose to pursue a career first in a new job and then went on to study. From tracer search studies, it was found that the majority of families of Husada Featured Vocational families came from the lower middle class. 


\section{Acknowledgement}

We express our gratitude to the supervisors and Board of Examiners who have provided a highly useful command. Thank you also to the Headmaster and staff who have provided the opportunity to conduct research at ISFI Pharmacy Vocational School and Unggulan Husada Vocational School. Additional Acknowledgments to the editorial of the j-k6em journal and all parties who have helped in the publication of this scientific work.

\section{References}

Alamsyah. (2019). School Based Management Implementation To Improve School Quality Of Multi Sites Study in SDN Alalak Selatan 2 and SDN Alalak Selatan 4 Banjarmasin City. . IJSDR.
Andriyani, e. (2018). Character Education Management. IOSR Journal of Research \& Method in Education (IOSR-JRME), I.

Djohar, A. (2007). Pendidikan Teknologi Dan Kejuruan,Dalam Ilmu Dan Aplikasi Pendidikan. Bandung: Pedagogiana Press.

Moh.Shofian. (2004). Pendidikan Berparadigma Perfektif. Yogyakarta: IRCisOD.

Permadi, M. (2019). The Relationship Of Work Motivation And The Use Of Communication and Information Technology (TIK) With Quality Service At Islamic School (MAN) In Banjarmasin, Indonesia. Alternative European Jurnal of Education Studies, 72.

Rachmadinoor. (2018). Role of School Heads in Improving Quality of Education. IJSDR, 72. 